\title{
Thermally Stable and Proton Conductive Ionogel Based on Brønsted Acidic Ionic Liquid with the Support of Silicate Network
}

\author{
By Tomonobu MIZUMo, Takeshi WATANABE, and Hiroyuki OHNO*
}

Thermally stable and water-free proton conductor based on Brønsted acidic ionic liquid and silicate network was prepared by sol-gel processing. As a Brønsted acidic ionic liquid, mixture of bis(trifluoromethyl sulfonyl)imide $\left(\mathrm{HTf}_{2} \mathrm{~N}\right)$ and 1-(1-ethyl-3imidazolio)butane-4-sulfonate (eim4S) was employed. The sol-gel process was successfully done, since the ionic liquid worked as acidic catalyst for the dehydration and the condensation reactions of tetramethoxysilane. Although the gel containing equimolar eim $4 \mathrm{~S}$ and $\mathrm{HTf}_{2} \mathrm{~N}$ showed high ionic conductivity, the thermal stability was poor because of sublimation of the $\mathrm{HTf}_{2} \mathrm{~N}$. Use of a small excess amount of eim4S effectively suppressed the sublimation of $\mathrm{HTf}_{2} \mathrm{~N}$. The obtained glassy ionogel showed high degradation temperature reflecting the thermal stability of both the silicate and the ionic liquid. The ionic conductivity reached to $10^{-3} \mathrm{~S} \mathrm{~cm}^{-1}$ at $150{ }^{\circ} \mathrm{C}$ without any humidification. Contribution of protons to the ionic conductivity was confirmed by chronoamperometry and impedance spectroscopy under hydrogen atmosphere.

KEY WORDS: Ionic Liquid / Polymer Electrolyte / Proton Conductor / Sol-gel Processing / Organic-inorganic Hybrid / Moderate

Temperature / Glass /

There are growing interests on fuel cells as environmentally clean and safe batteries. Among various types of fuel cell, polymer electrolyte fuel cells (PEFCs) have been attracting considerable attentions as the power supply for mobile devices. Current PEFCs employ Brønsted acidic polymers as proton conductive matrix. ${ }^{1-4}$ The polymers generate protons under wet condition and protons migrate in the continuous hydrogen bonding network of water molecules. However, those waterbased proton conductors are not suitable for the cells operated above $100{ }^{\circ} \mathrm{C}$ or below $0{ }^{\circ} \mathrm{C}$. The operation at higher temperature is important to enhance the cell voltage and to suppress the activity of carbon monoxide as a catalyst poison. Alternative proton conductors, durable at wider temperature range, have been accordingly investigated. ${ }^{5-9}$ Imidazole and the 2-substituted derivatives are recently examined instead of water because of their relatively small molecules having both proton donating site and proton accepting site. Imidazole-based proton conductor shows good ionic conductivity at the temperature above $100{ }^{\circ} \mathrm{C}$, though the thermal and chemical stability are waiting to be improved. ${ }^{10-14}$

Some ionic liquids are also expected as new proton conductors. ${ }^{15-17}$ Ionic liquids generally show high thermal stability beyond $300^{\circ} \mathrm{C}$, negligible vapor pressure, low glass transition temperature $\left(T_{\mathrm{g}}\right)$, and high ionic conductivity. ${ }^{18}$ Previously, we proposed a simple method to add acidity to ionic liquids by mixing appropriate zwitterionic salts and super strong acids such as bis(trifluoromethylsulfonyl)imide $\left(\mathrm{HTf}_{2} \mathrm{~N}\right) .{ }^{19}$ In such a binary system, imidazolium cationic part in the zwitterion forms low $T_{\mathrm{g}}$ domain with $\mathrm{Tf}_{2} \mathrm{~N}^{-}$, while the anionic part is neutralized to be acid form with proton. The mixture of 1-(1-butyl-3-imidazolio)propane-3-sulfonate and
$\mathrm{HTf}_{2} \mathrm{~N}$ showed ionic conductivity over $10^{-3} \mathrm{~S} \mathrm{~cm}^{-1}$ at $150^{\circ} \mathrm{C}$, as well as the decomposition temperature higher than $300^{\circ} \mathrm{C}$.

Gels including ionic liquid, called ionogels, are currently reported as ion conductor, ${ }^{20-23}$ actuator, ${ }^{24,25}$ luminescent materials, ${ }^{17,26}$ and several related electrochemical devices. ${ }^{18}$ As the host matrices of the ionogels, we used silicate network which was provided by sol-gel process. ${ }^{27}$ The sol-gel reaction was carried out in the presence of Brønsted acidic ionic liquid. The combination of ionic liquid and inorganic network should permit thermally stable proton conductive gel.

\section{EXPERIMENTAL}

\section{Materials}

1-(1-Ethyl-3-imidazolio)butane-3-sulfonate (eim4S) was used as a zwitterion. The eim4S was synthesized by the reaction of 1-ethylimidazole (TCI) with butanesultone (TCI), and used after recrystallization from acetone.

${ }^{1} \mathrm{H}$ NMR: (400 MHz, $\left.\mathrm{CD}_{3} \mathrm{OD}\right): \delta[\mathrm{ppm}] 1.54(3.0 \mathrm{H}, \mathrm{t}, J=$ $\left.7.3 \mathrm{~Hz}, \quad \mathrm{NCH}_{2} \mathrm{CH}_{3}\right), \quad 1.81-1.74\left(2.0 \mathrm{H}, \mathrm{m}, \quad \mathrm{NCH}_{2} \mathrm{CH}_{2} \mathrm{CH}_{2}-\right.$ $\mathrm{CH}_{2} \mathrm{SO}_{3}$ ), 2.09-2.02 (2.0H, m, $\left.\mathrm{NCH}_{2} \mathrm{CH}_{2} \mathrm{CH}_{2} \mathrm{CH}_{2} \mathrm{SO}_{3}\right), 2.84$ $\left(2.0 \mathrm{H}, \mathrm{t}, J=7.3 \mathrm{~Hz}, \mathrm{NCH}_{2} \mathrm{CH}_{2} \mathrm{CH}_{2} \mathrm{CH}_{2} \mathrm{SO}_{3}\right), 4.29-4.23(4.1 \mathrm{H}$, $\left.\mathrm{m}, \mathrm{NCH}_{2} \mathrm{CH}_{3}, \mathrm{NCH}_{2} \mathrm{CH}_{2} \mathrm{CH}_{2} \mathrm{CH}_{2} \mathrm{SO}_{3}\right), 7.66$ (2.0H, q, $J=$ $1.8 \mathrm{~Hz}, \mathrm{NCHNCHCH}), 9.03(0.2 \mathrm{H}, \mathrm{s}, \mathrm{NCHNCHCH})$.

Fresh white crystal of $\mathrm{HTf}_{2} \mathrm{~N}$ (gift from Morita Chemical Industries Co. Ltd.) was used as received. Because of its sublimation behavior, $\mathrm{HTf}_{2} \mathrm{~N}$ was treated in the grove box filled with dry nitrogen gas. Tetramethoxysilane (TMOS) purchased from TCI was used after distillation. 


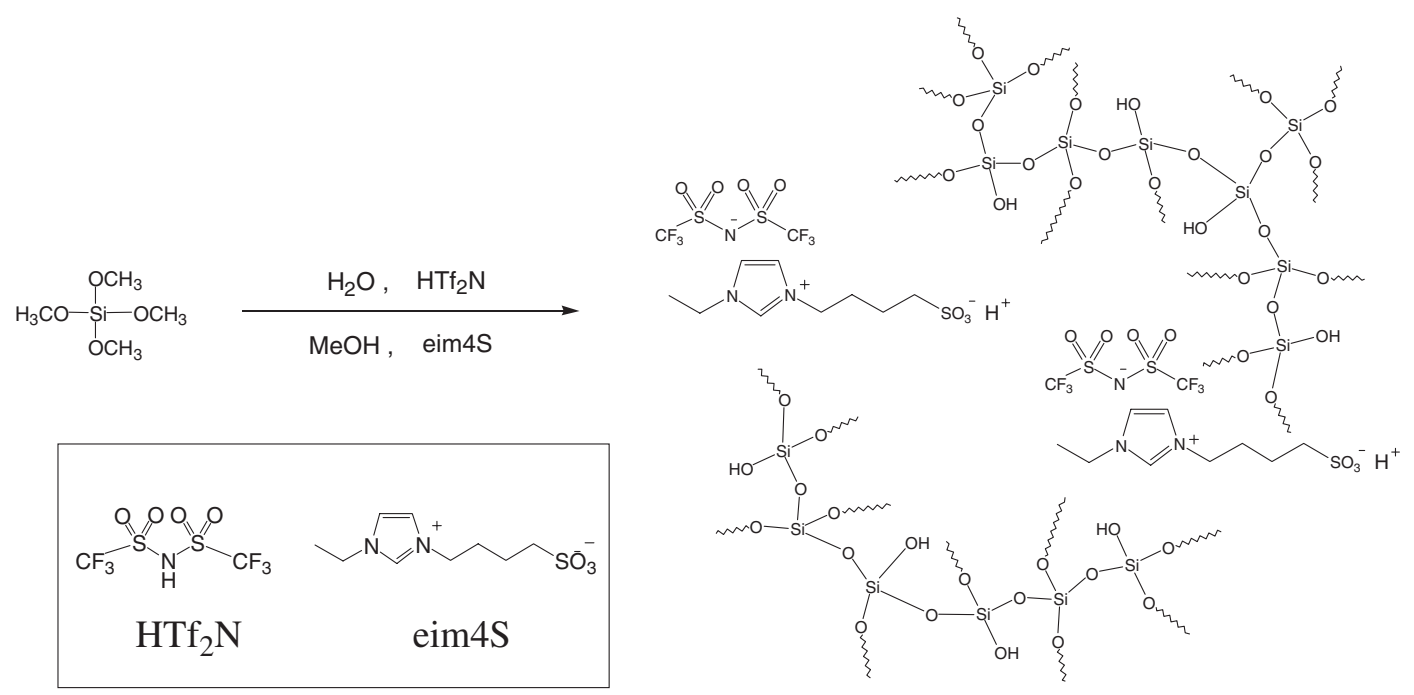

Scheme 1. Synthesis of silicate network entrapping Brønsted acidic ionic liquids.

\section{Preparation of Brønsted Acidic Ionic Liquids}

Brønsted acidic ionic liquid was prepared according to the method reported previously. ${ }^{19} \mathrm{HTf}_{2} \mathrm{~N}(1.29 \mathrm{~g}, 4.6 \mathrm{mmol})$ and equimolar eim4S $(1.23 \mathrm{~g}, 4.6 \mathrm{mmol})$ were dissolved homogeneously in $50 \mathrm{~mL}$ dry methanol in the ice bath then stirred for several hours. After removing methanol from the resulting solution under reduced pressure at room temperature, the eim $4 \mathrm{~S} / \mathrm{HTf}_{2} \mathrm{~N}$ equimolar mixture was obtained as a transparent liquid. Other ionic liquid/acid mixtures composed of eim4S and $\mathrm{HTf}_{2} \mathrm{~N}$ with molar ratio of $60 / 40$ and $67 / 33$ were prepared as well.

\section{Sol-gel Processing}

Silicates containing Brønsted acidic ionic liquids were prepared by sol-gel processing from the homogeneous solution of TMOS, eim4S and $\operatorname{HTf}_{2} \mathrm{~N}$ in methanol (Scheme 1). The solutions were introduced into an oven (ILW Vacuum Sample Oven HD-15D/3D) kept at $55^{\circ} \mathrm{C}$. Gelation occurred within $24 \mathrm{~h}$. The gels were aged for $14 \mathrm{~d}$ at $55^{\circ} \mathrm{C}$. The resulting gels were dried under reduced pressure at $80^{\circ} \mathrm{C}$ for $24 \mathrm{~h}$ prior to a series of characterization. The composition of the parental solutions for sol-gel processes is summarized in Table I. In this paper, the gels containing equimolar eim $4 \mathrm{~S}$ and $\mathrm{HTf}_{2} \mathrm{~N}$ are classified as "Group A." The gels classified in "Group B" contain two thirds molar $\mathrm{HTf}_{2} \mathrm{~N}$ to eim $4 \mathrm{~S}$, and the gels of "Group C" contain half molar $\mathrm{HTf}_{2} \mathrm{~N}$ to eim4S.

\section{Characterizations}

The ionic conductivities of the samples were determined by the complex impedance spectroscopy using Schlumberger Solartron-1260 impedance/gain phase analyzer, over the frequency range from 10 to $10^{6} \mathrm{~Hz}$ with the oscillating voltage of $100 \mathrm{mV}$. All the samples were vigorously dried before this measurement and operated in a glove box (UNICO 650F) filled with dry nitrogen gas. Samples were sandwiched in a custom designed cell constructed with a pair of stainless steel plates
Table I. Compositions of parent solutions for ionogels

\begin{tabular}{lcccc}
\hline & & TMOS & eim4S & $\mathrm{HTf}_{2} \mathrm{~N}$ \\
\hline $\mathrm{A} 1$ & $\mathrm{~g}$ & 1.00 & 1.00 & 1.05 \\
& $\mathrm{~m} \mathrm{~mol}$ & 6.57 & 3.73 & 3.73 \\
\cline { 2 - 5 } $\mathrm{A} 2$ & $\mathrm{~g}$ & 1.00 & 2.00 & 2.10 \\
& $\mathrm{~m} \mathrm{~mol}$ & 6.57 & 7.46 & 7.46 \\
\cline { 2 - 5 } $\mathrm{A} 3$ & $\mathrm{~g}$ & 1.00 & 3.00 & 3.15 \\
& $\mathrm{~m} \mathrm{~mol}$ & 6.57 & 11.2 & 11.2 \\
\hline $\mathrm{B} 1$ & $\mathrm{~g}$ & 1.00 & 2.00 & 1.40 \\
& $\mathrm{~m} \mathrm{~mol}$ & 6.57 & 7.46 & 4.98 \\
\cline { 2 - 5 } $\mathrm{B} 2$ & $\mathrm{~g}$ & 0.50 & 1.12 & 0.90 \\
& $\mathrm{~m} \mathrm{~mol}$ & 3.29 & 4.82 & 3.21 \\
\hline $\mathrm{C} 1$ & $\mathrm{~g}$ & 1.00 & 1.00 & 0.53 \\
& $\mathrm{~m} \mathrm{~mol}$ & 6.57 & 3.73 & 1.87 \\
\hline
\end{tabular}

with the aid of a polypropylene spacer. The spacer for solid samples defines the cell constant of $500 \mu \mathrm{m}$ thickness and $0.28 \mathrm{~cm}^{2}$ area. For liquid samples, the spacer with $100 \mu \mathrm{m}$ thickness was employed after calibrating the cell constant using $0.1 \mathrm{~mol} \mathrm{~L}^{-1} \mathrm{KCl}$ aq. The measurement temperature was dynamically varied from $160^{\circ} \mathrm{C}$ to room temperature with the rate of $-2.0{ }^{\circ} \mathrm{C} \mathrm{min}^{-1}$. The set of impedance data for each temperature was collected using custom designed apparatus.

Contribution of protons on the ionic conductivity was confirmed both by the chronoamperometry using Nikko Keisoku NPOT2501 and impedance spectroscopy using Solartron 1260. An electrochemical cell with carbon cloth-supported platinum electrodes $\left(0.5 \mathrm{mg} \mathrm{cm}^{-2}\right.$, ElectroChem Inc.) was used for the measurements. Square-shaped sample $\left(1.0 \times 1.0 \mathrm{~cm}^{2}\right)$ with $0.05 \mathrm{~cm}$ thickness was used for each measurement. The measurements were carried out under nitrogen or hydrogen atmosphere without any humidification.

Thermal properties of samples were evaluated by differential scanning calorimetry (DSC) and thermogravimetric analysis (TGA) using Seiko Instruments DSC120 and TG/ 
Table II. Ionic conductivity and thermal properties of Brønsted acidic ionic liquids

\begin{tabular}{|c|c|c|c|c|c|c|c|}
\hline \multirow{3}{*}{$\begin{array}{c}\text { eim4S/HTf } / \mathrm{H}_{2} \mathrm{~N} \\
(\mathrm{~mol} / \mathrm{mol})\end{array}$} & \multicolumn{3}{|c|}{$\sigma_{\mathrm{i}} / \mathrm{S} \mathrm{cm}^{-1}$} & \multirow[t]{3}{*}{$T_{\mathrm{g}} /{ }^{\circ} \mathrm{C}$} & \multicolumn{3}{|c|}{$T_{\mathrm{d}} /{ }^{\circ} \mathrm{C}$} \\
\hline & $30^{\circ} \mathrm{C}$ & $100^{\circ} \mathrm{C}$ & $150^{\circ} \mathrm{C}$ & & $1 \%$ & $10 \%$ & Shoulder \\
\hline & & & & & Loss & Loss & \\
\hline $50 / 50$ & $8.8 \times 10^{-5}$ & $1.8 \times 10^{-3}$ & $-^{a}$ & -59 & 71 & 277 & 352 \\
\hline $60 / 40$ & $0.46 \times 10^{-5}$ & $0.42 \times 10^{-3}$ & $1.68 \times 10^{-3}$ & -47 & 254 & 349 & 349 \\
\hline $67 / 33$ & $-^{a}$ & $7.6 \times 10^{-5}$ & $0.43 \times 10^{-3}$ & -37 & 304 & 337 & 323 \\
\hline $100 / 0$ & $-^{a}$ & $-^{a}$ & $-^{a}$ & $-^{\mathrm{b}}$ & 306 & 333 & 331 \\
\hline
\end{tabular}

a: not measured, ${ }^{\mathrm{b}}$ : not detected. eim4S showed melting temperature at $182^{\circ} \mathrm{C}$.

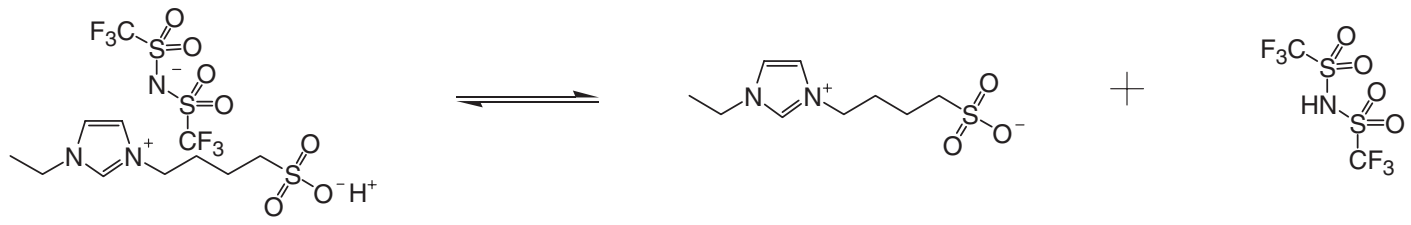

Scheme 2. Disproportionation of Brønsted acidic ionic liquid.

DTA 220, respectively. DSC measurement was carried out from $-140^{\circ}$ to $+150^{\circ} \mathrm{C}$ with sweeping rate of $+10^{\circ} \mathrm{C} \mathrm{min}^{-1}$. TGA was carried out under nitrogen gas atmosphere with the heating rate of $10^{\circ} \mathrm{C} \mathrm{min}-1$. Thermal stability of samples was also analyzed with TGA at constant temperature.

\section{RESULTS AND DISCUSSION}

\section{Brønsted Acidic Ionic Liquids}

Despite the solid nature of eim $4 \mathrm{~S}$ and $\mathrm{HTf}_{2} \mathrm{~N}$, the mixtures were obtained as liquids at room temperature. Table II summarizes the ionic conductivity and thermal property of a series of binary ionic liquids composed of eim $4 \mathrm{~S}$ and $\mathrm{HTf}_{2} \mathrm{~N}$. These were measured without the support of silicate network. With the increase of $\mathrm{HTf}_{2} \mathrm{~N}$ content, the ionic conductivity increased. The improved ionic conductivity is attributable to the increase of the carrier ion number (both proton and $\mathrm{Tf}_{2} \mathrm{~N}^{-}$) in the system, as well as the increase of the ion mobility that is suggested by the lowered $T_{\mathrm{g}}$. The ionic conductivity of the equimolar mixture achieved the highest value, $1.8 \times 10^{-3}$ $\mathrm{S} \mathrm{cm}^{-1}$ at $100^{\circ} \mathrm{C}$.

However, the equimolar mixture gradually lost the weight during the heat ramp of the TGA measurement. In contrast, both $60 / 40$ and $67 / 33$ mixtures did not show weight loss (1.0 wt \%) until $253^{\circ}$ and $304^{\circ} \mathrm{C}$, respectively. That of the pristine eim $4 \mathrm{~S}$ was $306^{\circ} \mathrm{C}$. The thermogravimetric losses should be attributed to the sublimation of $\mathrm{HTf}_{2} \mathrm{~N}$, caused by the disproportionation as shown in Scheme 2.

Figure 1 shows the time dependence of the thermogravimetry for those ionic liquids, where the applied temperature was constant at $208^{\circ} \mathrm{C}$ or $158^{\circ} \mathrm{C}$. At $208^{\circ} \mathrm{C}$, the equimolar mixture lost about $20 \%$ of weight, and the $60 / 40$ mixture lost $2.7 \%$ of weight. These two then reached steady states. As for the $67 / 33$ mixture, small change was observed during the measurement. To suppress the existence as $\mathrm{HTf}_{2} \mathrm{~N}$ at $208^{\circ} \mathrm{C}$, double-molar eim $4 \mathrm{~S}$ seems to be required. At $158^{\circ} \mathrm{C}$, the $60 / 40$ mixture did not show serious weight loss as shown in Figure $1 \mathrm{~b}$.

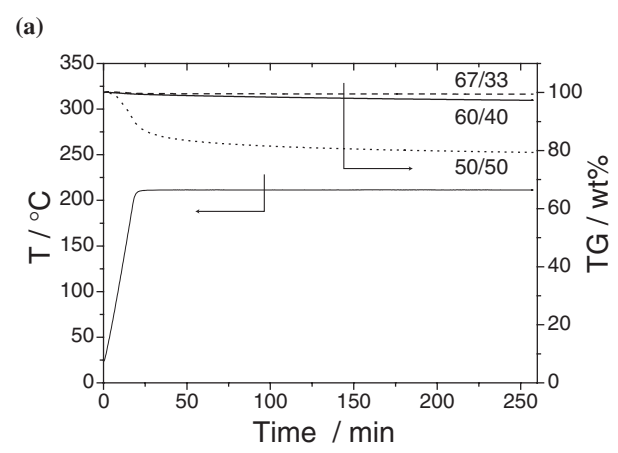

(b)

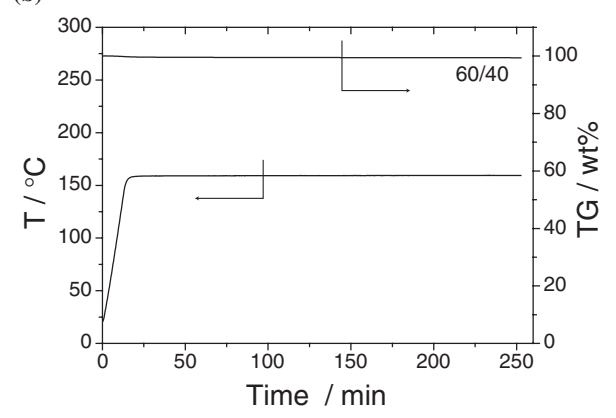

Figure 1. Thermogravimetric diagrams for a series of Brønsted acidic ionic liquids. Measurement temperature was held at $208^{\circ} \mathrm{C}$ (a) or $158^{\circ} \mathrm{C}(\mathrm{b})$.

\section{Appearances and Thermal Property of Ionogels}

The silicate network provided by the sol-gel process successfully solidified a series of Brønsted acidic ionic liquid. Figure 2 shows the appearance of a series of obtained ionogels. The present sol-gel process requires no conventional catalyst such as $\mathrm{HCl}$ and amines. In the present process, the ionic liquid as well as $\mathrm{HTf}_{2} \mathrm{~N}$ can behave as the acidic catalyst for the hydrolysis of TMOS and the following condensation reactions.

Figure 3 and Table III show the thermogravimetric data of ionogels. The apparent inorganic content in the gel was 


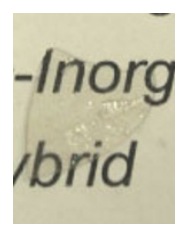

A1

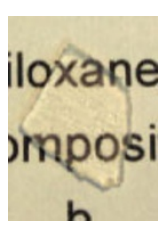

A2

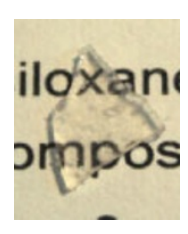

A3

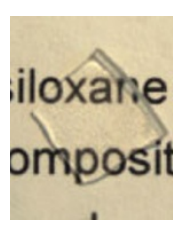

B1

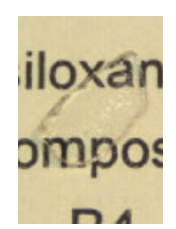

B2
Naicil

iie-Inol

Hybris

C1

Figure 2. Appearances of ionogels.

(a)

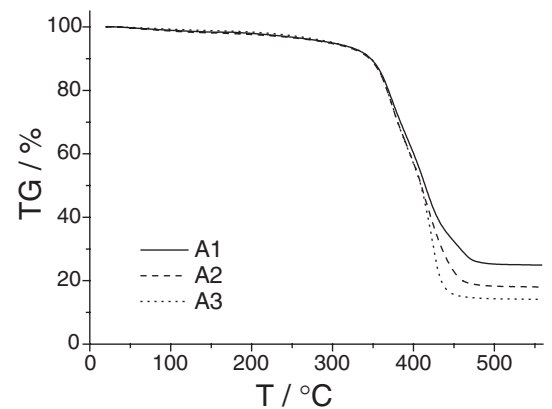

(b)

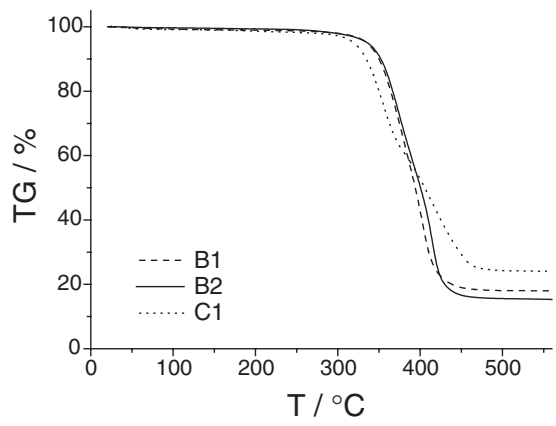

Figure 3. Thermogravimetric diagrams for ionogels including equimolar eim4S (a), or excess amount of eim4S (b) against $\mathrm{HTf}_{2} \mathrm{~N}$.

Table III. Decomposition temperatures for ionogels

\begin{tabular}{ccccc}
\hline lonogel & \% Loss & $\begin{array}{c}T_{\mathrm{d}} /{ }^{\circ} \mathrm{C} \\
10 \% \text { Loss }\end{array}$ & Shoulder & $\begin{array}{c}\mathrm{TG} / \% \\
\text { at } 550{ }^{\circ} \mathrm{C}\end{array}$ \\
\hline $\mathrm{A} 1$ & 100 & 347 & 351 & 25 \\
$\mathrm{~A} 2$ & 85 & 346 & 351 & 19 \\
$\mathrm{~A} 3$ & 131 & 348 & 353 & 14 \\
\hline B1 & 200 & 350 & 340 & 18 \\
$\mathrm{~B} 2$ & 250 & 353 & 345 & 15 \\
\hline C1 & 152 & 335 & 327 & 24 \\
\hline
\end{tabular}

estimated from the residual weight at $550{ }^{\circ} \mathrm{C}$. The inorganic content of a series of gel was ranged from $14 \%$ to $25 \%$, indicating that gels contain superior amount of ionic liquid. As shown in Figure 3a, samples in Group A gradually lost weight even at the initial stage of heating. The weight loss is ascribed to the sublimation of $\mathrm{HTf}_{2} \mathrm{~N}$, since the gels in Group A contain equimolar mixture of eim4S and $\mathrm{HTf}_{2} \mathrm{~N}$. On the contrary, the gels in Group $\mathrm{B}$ and $\mathrm{C}$ showed little change until $350^{\circ} \mathrm{C}$
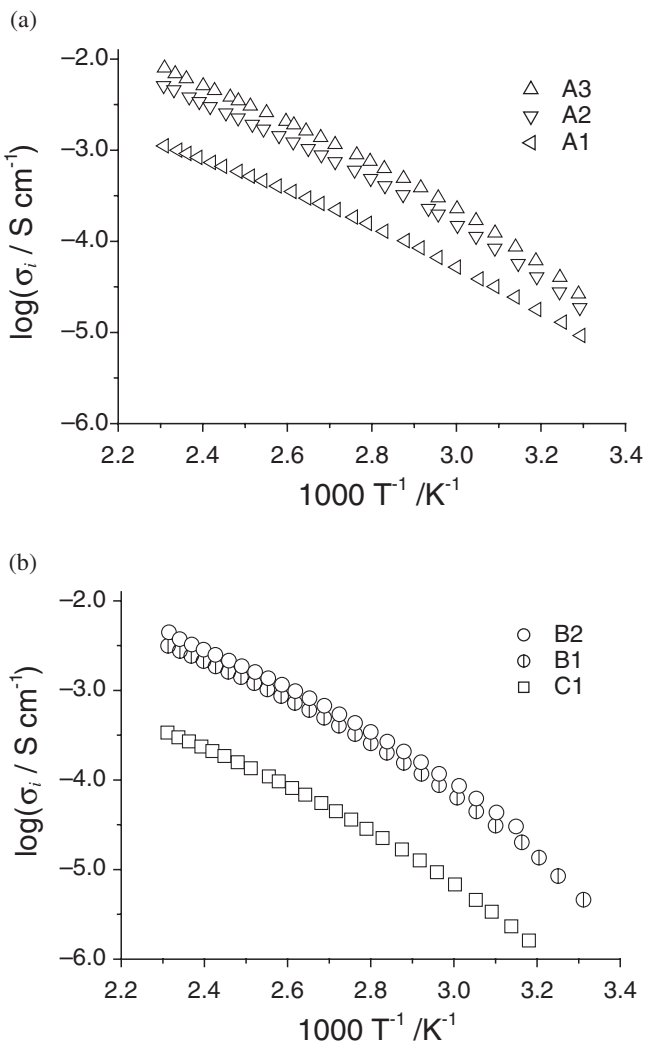

Figure 4. Temperature dependence of ionic conductivity for the ionogels including equimolar eim4S (a), or excess amount of eim4S (b) against $\mathrm{HTf}_{2} \mathrm{~N}$.

(Figure $3 \mathrm{~b}$ ). The sublimation of $\mathrm{HTf}_{2} \mathrm{~N}$ was suppressed by the excess amount of eim $4 \mathrm{~S}$ in these cases. The ionogel $\mathrm{B} 1$ was then kept at $150{ }^{\circ} \mathrm{C}$ for $6 \mathrm{~h}$ under $\mathrm{N}_{2}$ gas flow. During the measurement, $1.2 \%$ weight loss was observed for the sample, in spite of the thermal stability of the component ionic liquid (eim $4 \mathrm{~S} / \mathrm{HTf}_{2} \mathrm{~N}=60 / 40$ ) at $150{ }^{\circ} \mathrm{C}$ as shown in Figure $1 \mathrm{~b}$. The small weight loss for the resulting gel should be caused by the dealkylation of silicate, or further condensation of the remaining silanol.

\section{Ionic Conductivity of Ionogels}

Figure 4 shows the temperature dependence of the ionic conductivity for a series of ionogels. These upper convex curves show typical conduction of ions in viscous matrix. Accordingly, the ionic conductivity was fitted well on the Vogel-Fulcher-Tamman (VFT) equation as shown below. 
Table IV. VFT parameters for ionogels

\begin{tabular}{ccccc}
\hline lonogel & $\sigma_{0} / \mathrm{S} \mathrm{cm}^{-1}$ & $\mathrm{~B} / \mathrm{K}$ & $T_{0} / \mathrm{K}\left({ }^{\circ} \mathrm{C}\right)$ & $T_{\mathrm{g}} /{ }^{\circ} \mathrm{C}$ \\
\hline $\mathrm{A} 1$ & 0.471 & 584 & $164(-109)$ & -62 \\
$\mathrm{~A} 2$ & 0.762 & 490 & $184(-89)$ & -57 \\
$\mathrm{~A} 3$ & 1.269 & 607 & $177(-96)$ & -62 \\
\hline $\mathrm{B} 1$ & 0.943 & 592 & $190(-83)$ & -47 \\
$\mathrm{~B} 2$ & 1.090 & 606 & $186(-87)$ & -45 \\
\hline $\mathrm{C} 1$ & 0.316 & 547 & $197(-76)$ & -31 \\
\hline
\end{tabular}

$$
\sigma_{\mathrm{i}}=\sigma_{0} \exp \left(\frac{-B}{T-T_{0}}\right)\left(\sigma_{0}, B: \text { constants, } T_{0}: \text { ideal } T_{\mathrm{g}}\right)
$$

Table IV summarizes the VFT fitting parameters of every ionogel. Though the VFT equation indicates that higher ionic conductivity is found in the system with lower $T_{\mathrm{g}}$, no apparent relation between $T_{\mathrm{g}}$ and the conductivity was found in the present cases, because of different ion densities. As typically shown in data for the Group A (Figure 4a), the ionic conductivity was rather improved by the increase of the liquid content in the gel, indicating that the ionic conductivity was dominated by the carrier ion number in the gel.

Among the systems, the samples in Group A showed relatively high ionic conductivity. However, the conductivity gradually decreased owing to the sublimation of $\mathrm{HTf}_{2} \mathrm{~N}$ (eim4S/HTf $2 \mathrm{~N}=50 / 50$ ). For example, A3 showed the ionic conductivity of $6.0 \times 10^{-3} \mathrm{~S} \mathrm{~cm}^{-1}$ at $150{ }^{\circ} \mathrm{C}$ at the first scan, but the value of the second scan dropped to $4.2 \times 10^{-4} \mathrm{~S} \mathrm{~cm}^{-1}$. The ionic conductivity of B1 and B2 was comparable to those of A2 and A3, respectively (Figure 4b). The slightly lower ionic conductivity is caused by the inherent ionic conductivity of the component ionic liquid as shown in Table I. The ionic conductivity of the Group B did not show considerable change during several scans, since the ionic liquid contained in B1 or B2 (60/40 mixture) has adequate thermal stability at $150^{\circ} \mathrm{C}$. The sample $\mathrm{C} 1$ showed the lowest ionic conductivity, probably owing to the lowest ionic liquid content.

Proton is known to migrate in the matrix by hopping (Grotthuss mechanism) or diffusion of carrier (vehicle mechanism). The VFT-type behavior of ionic conductivity indicates that proton migrates in the system mainly by the latter mechanism. For the diffusion, proton cannot migrate as it is, but can do with $\mathrm{Tf}_{2} \mathrm{~N}^{-}$or eim4S. In the case of Group B and $\mathrm{C}$, protonated (acid form of) eim $4 \mathrm{~S}$ should be the dominant, since no $\mathrm{HTf}_{2} \mathrm{~N}$ exists in the presence of excess eim $4 \mathrm{~S}$ as suggested by TGA diagrams. In our preliminary study, we observed that a polymerized-eim $4 \mathrm{~S} / \mathrm{HTf}_{2} \mathrm{~N}$ mixture, on which zwitterionic site was bound, showed ionic conductivity lower than $10^{-6}$ $\mathrm{S} \mathrm{cm}^{-1}$ even at $100{ }^{\circ} \mathrm{C}^{28}$ The data also suggest that proton in the systems of B1, B2 and C1 migrates with the aid of zwitterions.

These gels contain both proton and $\mathrm{Tf}_{2} \mathrm{~N}^{-}$as mobile ions. Thus, we confirmed the contribution of proton on the ionic conductivity for sample B2 by chronoamperometry. Under $\mathrm{H}_{2}$ gas atmosphere, the following electrochemical reactions should occur at platinum electrodes.

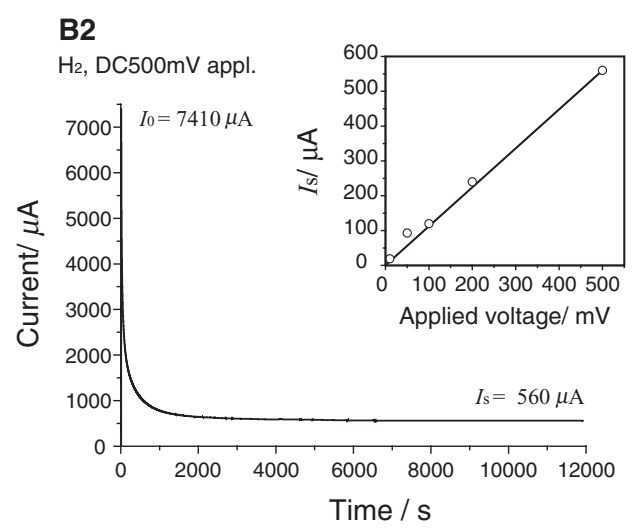

Figure 5. Time dependence of the current for $B 2$ at platinum electrode in DC500 mV, under hydrogen atmosphere. The insertion describes the steady state current values $\left(I_{\mathrm{s}}\right)$ by the function of applied voltage.

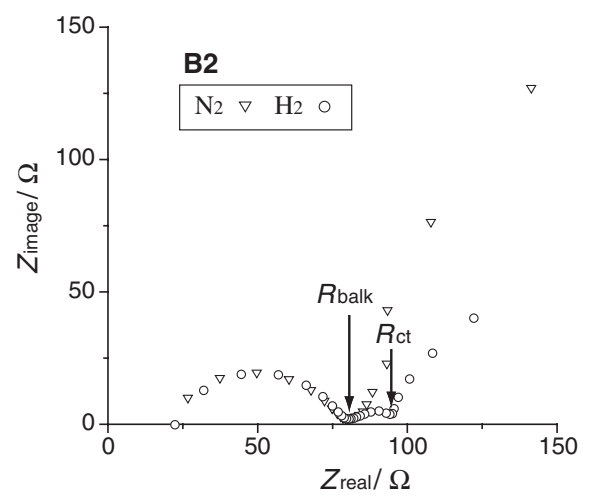

Figure 6. Nyquist plots for B2 at platinum electrode under hydrogen or nitrogen atmosphere.

$$
\begin{array}{ll}
\text { Anode: } & \mathrm{H}_{2} \rightarrow 2 \mathrm{H}^{+}+2 \mathrm{e}^{-} \\
\text {Cathode: } & 2 \mathrm{H}^{+}+2 \mathrm{e}^{-} \rightarrow \mathrm{H}_{2}
\end{array}
$$

All the measurements were carried out at $120^{\circ} \mathrm{C}$. Figure 5 shows chronoamperogram obtained under $\mathrm{H}_{2}$ atmosphere during a direct potential of $500 \mathrm{mV}$ applied. In the case of $\mathrm{N}_{2}$ atmosphere, the current promptly attenuated to nearly zero within a few seconds, suggesting the formation of electric double layer. Under $\mathrm{H}_{2}$ atmosphere, stable currents corresponded well to the applied voltages. Such stable currents cannot be explained by the electrodeposition or electrolysis of impurities. Employing the same electrochemical cell, impedance spectroscopy was carried out. As shown in Figure 6, two semi-circles appeared on the Nyquist plot under $\mathrm{H}_{2}$ atmosphere. The semi circle on the high frequency range relates the movements of ions in the bulk electrolyte $\left(R_{\text {bulk }}\right)$. The other one on the low frequency range relates the interfacial charge transfer between the electrolyte and the electrode $\left(R_{\mathrm{ct}}\right)$. In contrast, the semi-circle was not observed under the $\mathrm{N}_{2}$ atmosphere, because $\mathrm{N}_{2}$ gas was electrochemically inert to platinum electrodes in the present condition. 


\section{CONCLUSION}

Silicate network was obtained readily from TMOS at the presence of eim $4 \mathrm{~S}$ and $\mathrm{HTf}_{2} \mathrm{~N}$, permitting glass-like ionogel including Brønsted acidic ionic liquid. Acidic ionic liquid was beneficial not only as proton conductive media, but also as an acidic catalyst for the sol-gel reaction. The samples containing equimolar eim4S and $\mathrm{HTf}_{2} \mathrm{~N}$ (Group A) showed the highest ionic conductivity. However, these samples were thermally unstable due to the sublimation of $\operatorname{HTf}_{2} \mathrm{~N}$. The sublimation of $\mathrm{HTf}_{2} \mathrm{~N}$ was successfully suppressed by using excess amount of eim4S. When the composition of eim4S/ $\mathrm{HTf}_{2} \mathrm{~N}$ was $60 / 40$ (Group B), the resulting gel showed high ionic conductivity as well as thermal stability durable at $150{ }^{\circ} \mathrm{C}$. The ionic conductivity was above $10^{-3} \mathrm{~S} \mathrm{~cm}^{-1}$ in moderate temperature range without any humidification. The thermal stability arose from the inherent thermal stability of both the ionic liquid and the silicate network. The contribution of proton on the conductivity was confirmed by chronoamperometry and impedance spectroscopy. Sol-gel process using appropriate acidic ionic liquid should be a good method to obtain water-free proton conductors having excellent thermal stability.

Acknowledgment. The present study was carried out with the financial support by KAKENHI, a Grant-in-Aid for Scientific Researches (Nos. 19750108, 17073005, and 17205020) from the Ministry of Education, Culture, Sports, Science and Technology, Japan.

Received: July 7, 2008

Accepted: August 6, 2008 Published: September 18, 2008

\section{REFERENCES}

1. B. C. Steele and A. Heinzel, Nature, 414, 345 (2001).

2. M. Rikukawa and K. Sanui, Prog. Polym. Sci., 25, 1463 (2000).

3. C. H. Lee, H. B. Park, Y. S. Chung, Y. M. Lee, and B. D. Freeman, Macromolecules, 39, 755 (2006).

4. Z. Zhang, Z. Shi, X. Han, and S. Holdcroft, Macromolecules, 40,
2295 (2007).

5. K. Miyatake, H. Zhou, H. Uchiba, and M. Watanabe, Chem. Commun., 2003, 368 (2003).

6. Y. Chikashige, Y. Chikyu, K. Miyatake, and M. Watanabe, Macromolecules, 38, 7121 (2005).

7. G. Meyer, G. Gebel, L. Gonon, P. Capron, D. Marscap, C. Marestin, and R. Mercier, J. Power Sources, 157, 293 (2006).

8. Y. Yin, O. Yamada, K. Tanaka, and K. Okamoto, Polym. J., 38, 197 (2006).

9. S. Jacob, C. Poinsignon, and M. Popall, Electrochim. Acta, 50, 4022 (2005).

10. K. D. Kreuer, A. Fuchs, M. Ise, M. Spaeth, and J. Maier, Electrochim. Acta, 43, 1281 (1998).

11. A. Bozkurt and W. H. Meyer, Solid State Ionics, 138, 259 (2001).

12. A. Noda, M. A. B. H. Susan, K. Kudo, S. Mitsushima, K. Hayamizu, and M. Watanabe, J. Phys. Chem. B, 107, 4024 (2003).

13. G. Scharfenberger, W. H. Meyer, G. Wegner, M. Schuster, K.-D. Kreuer, and J. Maier, Fuel Cells, 6, 237 (2006).

14. M. Jeske, C. Soltmann, C. Ellenberg, M. Wilhelm, D. Koch, and G. Grathwohl, Fuel Cells, 7, 40 (2007).

15. W. Ogihara, H. Kosukegawa, and H. Ohno, Chem. Commun., 2006, 3637 (2006).

16. H. Nakamoto, A. Noda, K. Hayamizu, S. Hayashi, H. Hamaguchi, and M. Watanabe, J. Phys. Chem. C, 111, 1541 (2007).

17. J.-F. Huang, H. Luo, C. Liang, I.-W. Sun, G. A. Baker, and S. Dai, J. Am. Chem. Soc., 127, 12784 (2005).

18. "Electrochemical Aspects of Ionic Liquids," H. Ohno, Ed., WileyInterScience, Hoboken, 2005.

19. M. Yoshizawa and H. Ohno, Chem. Commun., 2004, 1828 (2004).

20. M. A. B. H. Susan, T. Kaneko, A. Noda, and M. Watanabe, J. Am. Chem. Soc., 127, 4976 (2005).

21. M.-A. Néouze, J. Le Bideau, P. Gaveau, S. Bellayer, and A. Vioux, Chem. Mater., 18, 3931 (2006).

22. T. Tezuka, K. Tadanaga, A. Hayashi, and M. Tatsumisago, J. Am. Chem. Soc., 128, 16470 (2006).

23. T. Tsuda, T. Nohira, Y. Nakamori, K. Matsumoto, R. Hagiwara, and Y. Ito, Solid State Ionics, 149, 295 (2002).

24. J. Ding, D. Zhou, G. Spinks, G. Wallace, S. Forsyth, M. Forsyth, and D. MacFarlane, Chem. Mater., 15, 2392 (2003).

25. T. Fukushima, K. Asaka, A. Kosaka, and T. Aida, Angew. Chem., Int. Ed., 44, 2410 (2005).

26. K. Lunstroot, K. Driesen, P. Nockemann, C. Görller-Walrand, K. Binnemans, S. Bellayer, J. Le Bideau, and A. Vioux, Chem. Mater., 18, 5711 (2006).

27. C. Sanchez, B. Julian, P. Belleville, and M. Popall, J. Mater. Chem., 15, 3559 (2005).

28. Z. Yang, D. H. Coutinho, D.-J. Yang, K. J. Balkus Jr., and J. P. Ferraris, J. Membr. Sci., 313, 91 (2008). 